\title{
NA TRINCHEIRA: pela defesa de uma concepção crítica do currículo
}

\author{
Júlio César Apolinário Maia \\ Universidade Federal de Jataí (UFJ)
}

\begin{abstract}
Resumo
Este estudo tem por objetivo parametrizar, em defesa dos pressupostos teóricos alicerçados por um bloco teórico marxista, o campo do currículo no bojo das teorizações críticas. Parte, a priori, de uma recapitulação deste campo no que concernem as décadas de 1960 e 1970, destacando a efervescência dada ao movimento reconceitualista para a edificação das teorizações críticas. Em segundo momento, pelo almejo à apresentação de ambos os blocos que assinalam tais teorizações, salienta a incoerência promulgada pelas pressuposições humanistas para com uma concepção crítica que faça jus ao ideal emancipatório do currículo. Em contraste, por conseguinte, outorga à crítica de um bloco teórico marxista, exclusivamente a partir da erudição de Michael Apple, a viabilidade de uma concepção crítica do currículo em benefício da materialização de um estado de contra-hegemonia em favor das classes subalternas.
\end{abstract}

Palavras-chave: Reconceitualização curricular. Teorizações críticas do currículo. Michael Apple.

\begin{abstract}
This study aims to parametrize, in defense of the theoretical presuppositions based on a theoretical marxist block, the field of curriculum in the bosom of critical theories. It begins with a recapitulation of this field with regard to the 1960s and 1970s, highlighting the effervescence given to the reconceptualist movement for the critical theorizations construction. Secondly, due to the presentation of both blocks that point to such theorizations, it emphasizes the incoherence promulgated by humanistic presuppositions towards a critical conception that lives up to the emancipatory ideal of the curriculum. In contrast, therefore, it attributes to the critique of a marxist theoretical block, especially from the erudition of Michael Apple, the viability of a curriculum critical conception in favor of materializing a counter-hegemony state in favor of the subaltern classes.
\end{abstract}

Keywords: Reconceptualization. Curriculum critical theorizations. Michael Apple. 


\section{Background em evidência: a efervescência do campo do currículo}

A autenticidade das teorizações reprodutivistas da educação, reconhecidas pelo subsídio viabilizado às reflexões acerca do papel do currículo, está na capacidade de compreender a estrutura e o funcionamento da escola capitalista enquanto um mecanismo de reprodução das relações sociais. "A divisão capitalista do trabalho; a exploração dos trabalhadores; a extração da mais-valia; a desqualificação do trabalho; o vaivém do desemprego; o exército industrial de reserva; a crescente dissociação entre trabalho manual e o trabalho intelectual [...]" (GADOTTI, 2001, p. 199) são características trazidas da organização do trabalho capitalista, averiguadas por Althusser (2001), Bowles e Gintis (1981) e Baudelot e Establet (1976), a fim de explicarem o trabalho regido pelo componente escolar. Dessa forma o papel da escola, muito antes de excitar as aptidões individuais dos seres humanos, aguilhoa os interesses estruturais de um mundo do trabalho sedento por mão de obra qualificada à particularidade de cargos e funções diversas.

Silva (2017) denota como o legado traçado por estas teorias se mostra, sobretudo no que tange as décadas de 1970 e 1980, repercutido nas atribuições dadas ao novo papel do componente educacional. Apesar de denunciada/criticada a lógica de percepção deste papel, assim como do papel do currículo (mesmo que ainda de forma indireta), enquanto unicamente o de veicular a reprodução das desigualdades e injustiças presentes nas relações sociais, ele se mostra de grande valia para a elevação de teorizações curriculares centradas na materialização de uma vontade subalterna, ou seja, na elucidação de um potencial de libertação representativo dos grupos (ou classes) sociais oprimidos.

Estas novas ideias, para além de se vincularem à herança concedida pelas teorias reprodutivistas, que tão-somente se relacionam à reprodução das disparidades sociais (na medida em que buscam estabelecer liga entre o currículo e uma multiplicidade de elementos, como estrutura e controle social, cultura, poder, ideologia etc.), aclara o desenvolvimento de movimentos e estratégias que reivindicam o ideal emancipatório característico aos estratos sociais marginalizados (MOREIRA e SILVA, 2005).

Eis as teorias críticas do currículo, conjecturadas, sobretudo, a partir dos ideais reconceitualistas (tanto marxistas quanto humanistas) norte-americanas. A presente investigação, não obstante, em vista da adoção de um referencial teórico designativo destas teorias críticas do currículo, tem por objetivo tanto refletir sobre a contraposição de pensamento entre seus diferentes blocos teóricos (humanista e marxista), assim como defender, sob específico respaldo da produção de Michael Apple, uma concepção de currículo aliada ao processo de emancipação dos grupos sociais subalternos, isto é, que assuma na representatividade ideológica do papel curricular (e não obstante do componente educacional enquanto organismo reprodutor e produtor de cultura), a opção de contraposição hegemônica, por parte destes grupos, aos interesses sociais hegemônicos e, não obstante, ao processo burguês de sociabilidade que se fortalece em seu entorno. A materialização da concepção aqui defendida se faz necessária na medida em que se presencia, em diálogo aos entendimentos de Apple (1997), nas intercorrências da conjunção escolar, assim como nos 
entrecruzamentos dos conhecimentos expressos pelos currículos de tal conjunção, a eclosão de inúmeros condicionantes segregacionistas.

\section{A insurgência de uma racionalidade outra à dinâmica curricular}

O movimento reconfigura a passagem de um currículo situado nos parâmetros administrativos e tecnocráticos canaliza todas as efervescências que caracterizaram a década de 1970 enquanto emissora de concepções contra-hegemônicas para se repensar a estrutura educacional (MALTA, 2013). A herança, obtida a partir das teorizações reprodutivistas, possibilita a emersão de um expressivo movimento negativo em relação ao caráter excludente e seletivo atribuído à dinâmica escolar e sua concepção técnica do currículo (SILVA, 2006). Conforme se fazia presente uma racionalidade curricular centrada num modelo tecnocrático de se pensar o processo de ensino-aprendizagem, aumentava-se a insatisfação de grupos sociais às práticas curriculares engajadas na perspectiva tradicional.

O silêncio que paira sobre as vozes dos professores e alunos, como expressa Pacheco (2000), gradualmente tende a ser preenchido pelo sentimento de rejeição ao modelo escolar orientado pelo princípio da eficiência, assim como pela especulação de formas alternativas de se pensar a dinâmica curricular. $O$ currículo passa, neste instante, pelo crivo das teorizações reprodutivistas, às quais recorrem os novos teóricos curriculistas em busca de soluções ao abismo reflexivo - ou "morte do currículo" enquanto campo de estudo, como supõem Schwab e Harper (1970) - aberto desde a década de 1960. Bem sabido, a assimilação das ciências sociais e filosóficas ao ideário destes novos teóricos é o fator que passa a validar a justaposição entre as teorizações reprodutivistas e as teorias críticas do currículo.

Apple, Au e Gandin (2011) denotam a importância do desenvolvimento de análises, durante a transição das décadas 1960 e 1970, expressivas da relação existente entre as estruturas sociais, econômicas e culturais e a própria experiência escolar. O enfoque dado à escola, responsável por oportunizar tal experiência, enquanto ferramenta de reprodução destas estruturas, caracteriza-se como centro das formulações críticas à época.

As teorizações reprodutivistas, compreendidas muitas vezes enquanto explanações deterministas da desigualdade existente no contexto educacional, tornam-se alvo sério de críticas advindas de pensadores que se preocupavam em navegar além do caráter reprodutivo cabível à escola. Saviani (2012, p. 17) compreende ser possível elucidar o caráter determinista cabível a estas teorias na medida em que elas se "[...] empenham em compreender a educação remetendo-a sempre a seus condicionantes objetivos, isto é, à estrutura socioeconômica que determina a forma de manifestação do fenômeno educativo". A constatação da determinação socioeconômica enquanto manipuladora da educação evidencia a funcionalidade básica da educação para estas teorias: a reprodução da sociedade. Percebe-se coerência, ao levar em conta a necessidade histórica pela formulação de uma nova organização do conhecimento escolar, nas críticas tecidas acerca das análises educativas baseadas exclusivamente nas relações de classe. Para além da exclusividade, a crítica elucida 
ainda a necessidade de desaprovação destas relações ao fato delas jazerem estanques, ou seja, limitarem-se à ordem reprodutiva das relações.

Diante da necessidade histórica pela ampliação da compreensão das relações sociais no ambiente educativo, uma série de teóricos passa a explicitar novas questões, até então escaramuçadas, no âmbito destas reflexões, dentre elas se destacam as relações de gênero e raça.

[...] a mobilização e os movimentos que surgiram feministas e das populações racializadas desafiaram diretamente a ênfase dada apenas às classes no trabalho crítico, tanto na reprodução social quanto na econômica. A própria noção de reprodução em si foi drasticamente desafiada no processo. Questões de contradição e conflito no âmbito dessas dinâmicas e entre elas tornaram-se cada vez mais significativas (APPLE, AU e GANDIN, 2011, p. 19, grifos meus).

A adoção de novas formas de interpretação das relações sociais no ambiente educativo se ampara a uma compreensão não técnica do currículo. A crítica a esta racionalidade tecnológica passa, neste tempo, a ser ensejada por uma série de pensadores, aglutinados e orientados a partir de um movimento conferencista de discussão acerca das necessidades concretas do campo curricular, assim como das tomadas de decisões cabíveis ante às necessidades da reconceitualização (PACHECO, 2000). Apesar de se estabelecer como vínculo, entre os pensadores deste movimento, a sensatez na inoperância de um modelo curricular enquadrado à atividade técnica e administrativa, deve-se destacar as individualidades que caracterizam cada parcela deste movimento, em virtude de seus distintos posicionamentos, assim como da familiaridade cabível às distintas influências teóricas assimiladas a estes. Silva (2017, p. 37) fortalece que no cerne deste movimento, sob influência de diferentes teorias sociais, florescem distintas identidades: "Aquilo que, nas perspectivas tradicionais, era entendido como currículo era precisamente o que, de acordo com aquelas teorias sociais, precisava ser questionado e criticado".

Pacheco e Pereira (2007) caracterizam o movimento de reconceitualização do currículo enquanto plural. Tal caráter, de acordo com esses autores, possibilita o desenvolvimento de horizontes contrários àqueles sugeridos pelos conceitos tradicionalistas, fazendo com que seja uma vez mais recorrente o hibridismo epistêmico aos estudos curriculares. Pacheco e Pereira (2007, p. 199) sustentam, ainda sobre o hibridismo caracterizante dos estudos curriculares, que "[...] diversas e contraditórias fronteiras disciplinares [...] lançam sobre o actual debate muitos desafios e muitas incertezas [...]", o que fomenta o entendimento de que as diferentes (e até divergentes) teorizações reprodutivistas, preponderantes sobre as vastas investidas teóricas dos novos curriculistas, repercutiram não de forma harmônica, mas derivadas de distintos paradigmas do conhecimento.

As familiarizações paradigmáticas de maior expressão, nos posicionamentos do movimento conferencista de discussão acerca das necessidades concretas do campo curricular, se vinculavam ora pela fenomenologia e hermenêutica, ora pelo marxismo e teoria crítica frankfurtiana (SILVA, 2017). Apresentavam-se, em virtude da reconceitualização do 
currículo, dois blocos teóricos com opiniões divergentes: o primeiro deles se ampara nos fundamentos fenomenológicos e hermenêuticos, enquanto o segundo se alia tanto à racionalidade marxista quanto crítica da Escola de Frankfurt; o primeiro bloco, de caráter humanista, acusa o segundo pelo menosprezo da experiência humana, aliando-a sempre à estrutura de classes e fazendo-a ausente de especificidade, criatividade, resistência e transcendência; o segundo bloco, em contrapartida, com afinidades marxistas, repreende o primeiro com relação à secundarização da base social em detrimento da experiência humana (MOREIRA e SILVA, 2005).

Vale destacar, antes de prosseguir com as teorizações críticas do currículo estabelecidas por cada um dos blocos, o não reconhecimento dos marxistas enquanto reconceitualistas. Este fato se dá em virtude dos movimentos conferencistas, especulativos da crítica ao currículo tradicional, terem em seu cerne a intenção de estabelecer justaposição entre as vertentes humanistas e marxistas. O bloco marxista, perante o qual se vinculam as formulações deste estudo, apesar de se estabelecer enquanto oposicionista ao modelo curricular técnico dominante, caracteriza-se também pelo recuo à concepção humanista e sua extrema concentração de questões subjetivas em detrimento às políticas (SILVA, 2017).

\section{As teorizações críticas do currículo sob a égide do bloco humanista}

O principal representante do bloco humanista, em contraposição a subordinação marxista da experiência humana à estrutura de classes, é William Pinar, que introduz a autobiografia como uma possibilidade de favorecer as "experiências vividas" no campo do currículo. Tais experiências significam, a partir dos pressupostos de Pinar, a estimulação de uma ação consciente, responsável e comprometida. As teses deste autor, como destaca Barriga (2016, p. 643), dirigem-se aos três seguintes pressupostos:

A educação não é um serviço prestado aos consumidores, mas uma oportunidade intelectual oferecida aos alunos, da mesma forma que aos próprios professores; Os professores não são burocratas que são submissos ao Estado, são intelectuais e artistas (ou deveriam ser quando abordam tarefas relacionadas com o currículo); O currículo é uma conversação complexa estruturada pelo compromisso ético com a alteridade (grifos meus).

Compreende-se que a tradição humanista característica às teorizações críticas do currículo, antes de se vincular a perspectiva autobiográfica evidenciada por Pinar, estabelece enquanto finalidade última a desnaturalização das atividades cotidianas a partir das experiências e significações subjetivas. Isso significa dizer que, ancoradas às pressuposições fenomenológicas, estas teorizações exigem que se coloque em suspensão o discernimento acerca das atividades cotidianas, tendo em vista que estas se situam no campo das aparências. Somente a partir desta condição de suspensão dos significados triviais característicos ao senso comum é que há expectativas de se peregrinar no sentido do estado essencial dos 
objetos. A experiência vivida, enlaçada da subjetividade, em contraposição ao que se estabelece no senso comum, capacita-se a exprimir as verdadeiras significações do objeto. Eis o fenômeno, recuperado no substrato das subjetividades e capacitado a manifestar o verdadeiro significado das experiências (SILVA, 2017).

Alcançar a áurea pura (ou epoché) significa recorrer à experiência vivida na ausência de todas as concepções constitutivas do ser (dos significados triviais cabíveis ao senso comum). Ao captar a experiência vivida em sua áurea pura, nasce uma capacidade de abstenção ao julgamento, e junto dela o entendimento das coisas em estado essencial, não mais enquanto verdade aparente (MARTINI, 1999). Fazendo uma aproximação da ótica fenomenológica com o campo do currículo, Silva $(2017$, p. 40) salienta que,

Para a perspectiva fenomenológica, com sua ênfase na experiência, no mundo vivido, nos significados subjetivos e intersubjetivos, pouco sentido fazem as formas de compreensão técnica e científica implicadas na organização e estruturação do currículo em torno de disciplinas. As disciplinas tradicionais estão concebidas em torno de conceitos científicos [...] e não [...] das experiências diretas. No máximo, as disciplinas e matérias tradicionais aparecem como categorias a serem questionadas.

Souza (1993), ao apresentar a obra de Joel Martins, "Um enfoque fenomenológico do currículo: educação como poiésis"1, sustenta o privilégio da subjetividade enquanto caráter fundamental desta abordagem. A experiência individual confere veracidade ao ato de aprender, ou seja, somente o que é aprendido por intermédio das experiências individuais passa a ser fidedigno. O currículo nesta perspectiva tem caráter crítico pois se vincula exclusivamente a análise dos significados das atividades cotidianas, questionando a consolidação natural das experiências humanas. Portanto, age enquanto interrogação às abstrações e conceitos teóricos estipulados na perspectiva curricular tradicional. Silva (2017) pondera que, a priori, as próprias categorizações estabelecidas pela perspectiva curricular tradicional com relação ao ensino, confrontadas na concepção fenomenológica pelo papel carcerário que sujeitam aos estudantes e professores, devem ser submetidas ao alcance da áurea pura. Posteriormente a experiência dos estudantes é levada em consideração, o que viabiliza a oportunidade de ser encontrado seu significado singular - ausente dos equívocos do senso comum e das abstrações científicas - ou o sentido essencial.

O enfoque fenomenológico não considera ser, o currículo, um instrumento imbuído de conceitos didático-pedagógicos (tal como objetivo, metodologia, conteúdo e avaliação). Em contraposição a tal "abstração", o currículo exprime a relação estabelecida entre a vida humana, considerando o conjunto de suas experiências, e o mundo da educação, constituído por uma série de componentes sujeitos à atribuição de significados advindos da consciência humana. "Por isso, ao construir currículo, deve-se preocupar sobretudo, com as possibilidades efetivas de o aluno apropriar-se de sua experiência educacional integrando-a à estrutura da consciência e incorporando-a como forma de estar-aí-no-mundo" (SOUZA, 1993, p. 122). 
A tendência da literatura que se debruça sobre a análise fenomenológica do currículo pela investigação de temas relacionados às experiências da vida cotidiana no âmbito educativo, faz com que ela seja, muitas vezes, alvo de comentários céticos tendenciosos a associar sentido de banalidade à sua finalidade investigativa. O que buscam estas investigações, em suma, é dar significância ao caráter singular atribuído a cada uma destas experiências da vida cotidiana (SILVA, 2017).

Existe forte vínculo estabelecido entre a análise fenomenológica e duas outras estratégias investigativas: a primeira delas se fundamenta nas pressuposições de Max van Manen, no momento em que este difunde o conceito de "hermenêutica fenomenológica"; o segundo se relaciona à autobiografia, sendo amparado, sobretudo, pelos pressupostos teóricos de Pinar (SILVA, 2017).

Ao se aliar à hermenêutica, o enfoque fenomenológico amplia o entendimento de essência, fazendo com que este transcenda o estágio de significado uno (fundamentado a partir de uma experiência), e se complexifique ao acatar a lógica das múltiplas interpretações, advindas de várias experiências e significações. Vieira e Rivera (2012, p. 269) corroboram para a compreensão da hermenêutica ao assegurarem ser, por meio das experiências, " [...] possível vislumbrar a possibilidade de interpretação dos significados atribuídos pelos sujeitos à condição social de estar no mundo (organização) e, por meio de suas expressões e relatos, chegar a compreender suas ações".

A autobiografia em Pinar, por vez, restringe-se em maior demasia ao currículo, sobretudo em diálogo a sua concepção de "experiência vivida". Ao situar a educação enquanto oportunidade intelectual, os professores enquanto cultos e artistas, e o currículo enquanto compromissado à alteridade, Barriga (2016) evidencia as características comuns a autobiografia. Tais características (sentido educativo, professores e currículo) elucidam o entendimento do que o autor denomina "experiência vivida", pois edificam uma ponte entre o conhecimento escolar, a história de vida e o desenvolvimento das capacidades individuais, e agem não enquanto ferramentas de revelação dos aspectos formativos, mas como naturalmente formativas da condição humana. Silva $(2017$, p. 44) assegura que "[...] na perspectiva da autobiografia, uma maior compreensão de si implica um agir mais consciente, responsável e comprometido".

Pinar sugere que a "experiência vivida", por ser naturalmente formativa da condição humana, pode examinar com eficácia o contexto educacional. Basta que as experiências, episódios, sentimentos, saberes e demais aspectos característicos ao exame autobiográfico da experiência escolar sejam trazidos à tona (SILVA, 2017). Pacheco (2009) diz ser impossível para o exame autobiográfico, ao compreender os rudimentos do campo educacional, agir fora da realidade subjetiva. Este fato confirma a necessidade de se investigar com base nas identidades, nas relações estabelecidas com os outros e nos laços estruturados no tracejo do tempo e espaço de cada vivência.

O fato de não se limitar ao papel revelador dos aspectos formativos da condição humana, mas se propor, em contrapartida, naturalmente enquanto formativa, faz da autobiografia uma proposta transformadora. Pinar estrutura esta proposta a partir da ênfase dada à experiência pessoal sobre as práticas curriculares. Este autor conceitua tal ênfase como método currere, 
ou método de registro das atividades que propiciam a compreensão da experiência no campo educacional. O método currere, para Pacheco (2009), utiliza princípios da fenomenologia e da psicanálise para realçar depoimentos característicos à experiência subjetiva dos indivíduos. Os recursos analíticos da psicanálise, ao estudarem a instauração da subjetividade, engrandecem os escopos fenomenológicos (SILVA, 2017). Já os depoimentos, aprimorados da experiência subjetiva, adolescem-se a partir de questões que fidedignamente busquem representar a consciência histórica do sujeito, tornando a noção de significação atrelada a valorização da consciência (PACHECO, 2009).

A autobiografia, assim como sua ênfase dada à experiência pessoal no campo curricular (método currere), tende a se manifestar enquanto um espaço de reflexão da ação docente. Silva (2017) explica que esta tendência pode se relacionar ao fato da pesquisa autobiográfica não se conciliar às particularidades das inquirições racionalistas cabíveis às ciências sociais, o que a torna tanto arbitrária à forma de organização curricular "oficial", quanto favorável à investida de outra lógica de organização, centrada na experiência educacional docente.

Ranghetti (2004, p. 1) elucida a importância da autobiografia aliada à área de formação docente:

O exercício de (re)olhar-se na tentativa de aproximar-se do início do fio que tece/teceu a trama do próprio mundo vivido, possibilita rever-se no cenário de um tempolespaço de formação, e filtrar, das experiências vividas, das afecções sentidas, o movimento destes tempos/espaços históricos. Isto desafia a questionar o sentido que o ser humano, em especial, o ser humano professor atribui à formação profissional. Ser professor é uma constituição singular que vai tomando forma no processo da própria existência, sobretudo porque $a$ ação de ensinar suscita uma aprendizagem permanente, contínua, marcada pela 'descontinuidade' da passagem de aluno a professor (grifos meus).

A consciência histórica do professor, a este sentido, remonta o percurso formativo de sua prática profissional. Torna-se necessário explorar as experiências acarretadas no decorrer da trajetória acadêmica para compreender suas influências no próprio comportamento docente. Dessa forma se torna difícil mensurar a contribuição da autobiografia ao currículo, tendo em vista seu caráter emancipatório e sua necessidade de recorrer às experiências firmadas durante a formação inicial para elucidar os significados e projetar transformações positivas na ação do professor (RANGHETTI, 2004). A existência de uma restrição ao desvelamento do sentido da ação docente, todavia, fomenta uma crítica a esta perspectiva. A crítica pressupõe não se mostrar aclarada a ampliação da autobiografia enquanto um recurso capacitado à emancipação educacional dos demais componentes do contexto educacional (SILVA, 2017).

Não há como, portanto, conferir à perspectiva autobiográfica a coerência necessária de uma abordagem que se emprenha para identificar o sentido do currículo. Para além de sua literatura ser restrita às experiências formativas da docência, existem elementos que expressam a contradição existente nestas experiências, fazendo com que elas acabem muito mais se intentando pela compreensão de ações espontâneas do que estabelecendo um sentido 
verídico ao papel curricular. A compreensão do percurso formativo de um indivíduo vinculado a um contexto socioeconômico favorecido, por exemplo, pode ser representativa do comportamento docente de forma generalizada? O caráter subjetivo como valor de conhecimento é pura compreensão relativista do papel docente, ou seja, a realidade lida do ponto de vista de um único indivíduo se descompromete ao estabelecimento de juízo de valor (assim como de estranhamento) aos acontecimentos.

Ao se aliar à fenomenologia (e mesmo que à hermenêutica), a autobiografia se ajunta também à filosofia, que possui intento divergente à ciência: enquanto a primeira busca descobrir o sentido da natureza, a segunda se dedica a prospectiva da melhoria da vida humana. Dessa forma, grávida pelo sustentáculo filosófico, a perspectiva autobiográfica não estranha o "natural", logo não aponta mudanças sociais, por mais que busque projetar transformações positivas à ação docente. O estranhamento ao "natural" e a projeção de um ideal emancipatório, em contrapartida, é fator crucial às teorizações críticas marxistas do currículo. Não é por acaso que, ao se verem encaminhados a uma vala comum a partir do desígnio reconceitualista, estes teóricos recusam a intencionalidade dos movimentos conferencistas, assim como a justaposição de suas ideias, de ordem política, àquelas vinculadas ao bloco humanista, de ordem subjetiva. Eis porque Pacheco e Pereira (2007) compreendem o currículo enquanto uma área de conhecimento fundamentalmente caracterizada por um contínuo conflito epistemológico, um hibridismo que desde a própria gênese, ao sofrer influências de diversas e díspares fontes de conhecimento, se manifesta de forma potencial e contraditória, lançando sobre os debates acadêmicos hodiernos uma gama de incertezas e desafios.

A não projeção de um ideal emancipatório expressa o atual enfrentamento à solidificação de uma concepção curricular aliada às teorizações críticas que se banham de um referencial marxista. $\mathrm{O}$ constructo relativista, que se origina ante as contestações do bloco humanista durante o período reconceitualista passa a se dissipar em meio a uma gama de novas influências, encontrando um aconchego nas "soluções" pós-estruturalistas, pós-modernas e dos estudos culturais em sua amplitude (SILVA, 2017), soluções estas, limitadas às intencionalidades fenomenológicas, hermenêuticas e autobiográficas, centradas na estruturação de análises subjetivas e narcisísticas da compreensão do currículo, assim como da realidade (APPLE, 1995).

\section{A coesão das teorizações críticas do currículo sob a ótica marxista}

A crítica marxista, em incongruidade ao bloco humanista, urge de uma desaprovação do constructo escolar pautado na educação liberal. Este dissentimento, posto décadas antes via concórdia das teorizações reprodutivistas, passa agora a elaborar uma análise reflexiva acerca do papel curricular imbuído à dinâmica da escola capitalista. Passa a serem questionadas as finalidades hegemônicas acometidas ao aparato escolar. Apple (1982), em decorrência deste fato, enfaticamente progride sobre o desígnio do aparato escolar tanto como garantia à expansão do conhecimento técnico a uma parcela de estudantes - preparando-os à 
consecução dos altos níveis de ensino e detenção do poderio econômico -, quanto, em contrapartida, ao fomento do "pseudo-compartilhamento" deste próprio poderio econômico sob a égide da introdução de um conjunto de princípios e valores representativos do que convencionalmente passa a se figurar como "normalidade" e "desvio" para o avanço educacional. Este avanço se relaciona a uma lógica de priorização aos interesses sociais e econômicos de grupos sociais dominantes, que, de forma geral, orientam e selecionam a organização curricular.

Em meio à efervescência comportada pelas décadas de 1970 e 1980, Michael Apple passa a contribuir teoricamente para a análise de questões curriculares e educacionais. Desmascarando um discurso que a fio se dedicava à procura de boas respostas ao ensino nos agrupamentos escolares, Michael Apple se dedica a entender "o que" está sendo ensinado e “a benefício de quem”. Ambas as ponderações, até então ausentes aos debates científicoacadêmicos do campo educacional, coloca em xeque toda a rigidez identificada na racionalidade tecnicista do currículo, assim como projeta novos conceitos em busca de um entendimento que não só aproxime as relações educacionais da dominação econômica impregnada aos arranjos do capitalismo, como também desenvolve uma nova linguagem comprometida à fundamentação de um nexo existente entre estrutura educacional e estrutura social (GANDIN, 2011).

Vale-se Apple (1982), para tanto, de uma série de conceitos que lhe propiciam saltar sobre o determinismo fundamentado em vertentes marxistas de caráter economicista, as quais conferem sentido reducionista à esfera cultural, na medida em que a conceituam enquanto mero reflexo econômico. Gandin (2011) salienta que dentre os conceitos que propiciam Michael Apple a identificar a centralidade da esfera cultural no interior das análises sociais, e a partir disto ater-se às mediações que asseguram a ação das relações econômicas sobre a cultura, destacam-se as ideias de ideologia, hegemonia, senso comum e saturação.

Eis porque Michael Apple contesta a concepção de ideologia posta em Althusser (GANDIN, 2011), enfatizando-a enquanto determinista por não captar as contradições caracterizantes do processo de dominação. O desconhecimento destas contradições implica num afrontamento ao papel do sujeito para com a interposição de uma resistência sobre o determinismo ideológico que a ele se mostra imposto. A relação estabelecida entre poder econômico e poder cultural pode antecipar a abertura dada por Apple (1982, p. 98 e 99) ao estudo das contradições existentes no processo de dominação:

[...] a capacidade de um grupo tornar seu conhecimento em 'conhecimento para todos' está relacionada ao poder desse grupo no campo de ação político e econômico mais amplo. Poder e cultura, então, precisam ser vistos, não como entidades estáticas sem conexão entre si, mas como atributos das relações econômicas existentes numa sociedade. Estão dialeticamente entrelaçados, de modo que poder e controle econômico estão interligados com poder e controle cultural (grifos meus). 
Enquanto produto de relações econômicas singulares a um dado contexto social, a articulação estabelecida entre poder e cultura parece não tomar uma proporção determinista. Não validar o reflexo desta articulação unicamente com base na tendência economicista, significa compreender a existência de conflitos presentes no processo de dominação e de mediações que tornam propícia a legitimação do "conhecimento oficial", ou seja, as tendências (regras, normas de trabalho, rotinas etc.) e significados (conhecimentos, saberes, práticas) formalmente encaminhados pela escola. Dessa forma entende-se que a escola passa a não controlar somente pessoas, mas os significados e tendências atribuídos às pessoas, que se encontram a mercê de uma visão de mundo formulada por ideologias hegemônicas.

A premissa de Apple, em fuga às vertentes economicistas que analisam o papel ideológico, caracteriza-se pelo suscitar de um auto-reconhecimento crítico a seus leitores (sobretudo educadores) permissível à compreensão da íntima relação existente entre educação e as configurações desiguais propiciadas pelas forças sociais de larga escala ${ }^{2}$, como também da captação, a partir desta relação, do vislumbre de superação deste contexto desigual, ou seja, de uma ótica centralizada num caráter político e ético que assegure (ou busque sempre assegurar) os seguintes princípios: equidade, compartilhamento, dignidade pessoal, segurança, liberdade e compaixão. Esta ótica, ou seja, este auto-reconhecimento crítico guarnece atenção ao valor da dignidade humana, da competente função transformativa que está associada ao sujeito enquanto co-responsabilizado e envolvido com as políticas de finalidades democráticas concernentes as esferas sociais que se encontra envolvido (APPLE, 1997).

Apple (1982) vale-se de duas premissas para a elucidação da proporcionalidade direta existente entre poder/controle político-econômico e poder/controle cultural. A primeira caracteriza-se pela falta de autonomia, estabelecida pela escola, sobre as demais instituições com as quais se vincula. A autonomia, pelo contrário, estabelece-se na contramão desta relação, na medida em que advém de instituições (econômicas, políticas e culturais), capacitadas a projetar, sobre a escola, uma espécie de poder fragmentário que infere sobre o acesso e recursos e propõe, em larga escala, o fomento à desigualdade.

A segunda premissa, somada à especulação de um conhecimento escolar reprimido pelas rédeas de instituições políticas, econômicas e culturais, fomenta a tese principal de Michael Apple. Esta premissa trata do reforço dado, a partir do currículo, ao poder fragmentário anteriormente comentado. Desta forma, para além do fomento concebido à desigualdade estrutural, a partir da carente autonomia da função escolar frente a guarda das instituições de poder, à escola acaba sendo concebido o papel de marionete, que passa a lhe fazer atender, via currículo, à segregação inicialmente almejada pelas instituições detentoras de poder político, econômico e cultural. O reflexo deste processo se apresenta no cotidiano das salas de aula, nas atividades pedagógicas e avaliativas adotadas pelos professores, assim como em outros tantos mecanismos capacitados à "reprodução cultural das relações de classe" (APPLE, 1982, p. 99).

Ambas as premissas configuram o norte elucidativo encontrado por Apple ao se dedicar às reflexões contidas em "Ideologia e currículo". Elucidativo na medida em que revela uma necessidade básica a ser levada em conta por educadores comprometidos à contraposição da 
desigualdade estrutural evidentemente presente nas relações da escola capitalista. Tal necessidade, a partir da própria argumentação de Apple (2006, p. 36), se configura enquanto um conselho aos educadores que também se reconhecerem enquanto seres políticos. Tal conselho confirma a precisão de se "[...] começar a encontrar maneiras de entender como os tipos de recurso cultural e símbolos que as escolas escolhem e organizam estão dialeticamente relacionados aos tipos de consciência normativa e conceitual 'exigidos' por uma sociedade estratificada".

Compreender a afinidade estabelecida entre valor cultural, simbólico e o processo educativo, significa projetar uma reflexão acerca de tal processo, levando em conta sua conformidade para com a estratificação e a desigualdade social, para além da esfera econômica. O norte estruturado por Apple (anteriormente escrito) aclara a importância de um esforço de concentração, por parte dos educadores, para com uma segunda esfera de operacionalização da escola. A esfera econômica, a priori, evidencia o arranjo pelo qual a educação reproduz a expressividade das relações de desigualdade. A esfera cultural, tal como a econômica, é essencial alvo de análise do ponto de vista educacional, pois evidencia a escola enquanto uma instituição de formação de consciência capacitada à preservação e distribuição de uma cultura dominante, eximindo, de tal forma, o apelo a mecanismos apelativos por parte da classe hegemônica, na medida em que os padrões culturais que respondem aos seus interesses são frequentemente acatados (APPLE, 2006).

Enquanto instituição de formação de consciência que corrobore a proliferação de uma cultura legitimada, a escola não pode simplesmente ser interpretada enquanto mera instituição de reprodução onde os estudantes são passivamente moldados para a vida em uma sociedade injusta. Limitar-se a este entendimento significa tanto estabelecer neutralidade metodológica à análise do currículo, como ausentar-se da relação existente entre o aparato educacional e as esferas política, econômica e cultural. Significa também possuir um precário respaldo histórico enquanto guarnição ao estudo do papel educacional, vinculando-o sempre à racionalidade processo/produto, onde há limitado entendimento do processo educacional enquanto exclusivamente adaptado ao controle/formação de trabalhadores em função das necessidades produtivas. Apple (1989) assinala que tal neutralidade metodológica, ao se eximir de uma analise consistente que passe a considerar intersecção entre instituições políticas, econômicas e culturais para com aparato educacional, torna também desnecessária a resposta à questão inicialmente proposta em seus estudos: "o conhecimento de quais grupos deveria ser ou já estava sendo preservado e transmitido na escola?” (p. 29).

A tentar compreender a relação existente entre currículo e reprodução, Apple (1989) se afasta da superficialidade concebida à neutralidade metodológica, confrontando a interpretação da escola como instituição de reprodução das relações sociais. O confronto nasce a partir da elucidação do conceito de legitimação. A legitimação, para além das categorias anteriormente elucidadas em Gandin (2011) - que possibilitam compreender Apple a partir do nexo desenvolvido entre a ação das relações econômicas e culturais - acaba se afirmando enquanto elemento chave para a manutenção das bases estruturais da desigualdade no contexto escolar, pois ante a necessidade de reproduzir estas bases, se apresenta também a consolidação de instituições e ações legitimadas. A consagração destas 
ações e instituições possibilita ir ao encontro daquela formação de consciência anteriormente elucidada, que corrobora para com a proliferação da cultura hegemônica. Sobre a legitimação, Apple (1989, p. 29 e 30) assim se expressa:

Um dos problemas fundamentais que temos que encarar é o da forma através da qual os sistemas de dominação e exploração persistem e se reproduzem sem que isto seja conscientemente reconhecido pelas pessoas envolvidas. Isto tem particular importância na educação, uma área na qual nossas práticas comumente aceitas procuram tão claramente ajudar os estudantes a solucionar muitos dos "problemas sociais e educacionais" que enfrentam. [...] a classificação [...] baseada no senso comum tende a confirmar e a reforçar essas relações [...] de dominação. Pois "atores conscientes, racionais, bem intencionados" muitas vezes contribuem - simplesmente pelo fato de perseguir seus próprios fins subjetivos para a manutenção dessas relações estruturais (grifos meus).

Uma classificação, pois, atinge sua máxima eficácia em favor da legitimação ao ser naturalizada e identificada enquanto senso comum (SILVA, 2017). É clara a ironia de Apple ao vincular o estado de culpa pela legitimação de instituições e ações hegemônicas à conscientização, racionalidade e boa intenção dos atores que se encontram vinculados ao contexto educacional. O estado de consciência, racionalidade e boa intenção, por este autor, é batizado justamente enquanto propício à seguridade do convencimento ideológico dos grupos dominantes. Apple (1989) analisa tal convencimento com base na ótica gramsciana, uma vez que há aproximação do papel dos "atores bem intencionados" à função dos "intelectuais", ou seja, ambos operam a partir da difusão e legitimação dos significados e práticas favoráveis à ideologia dominante. A este sentido se torna evidente a configuração do educador enquanto intelectual (ainda que inconsciente) capacitado à conscientização de indivíduos em prol da ideologia dominante, que naturalmente se encontra engrandecida pelo senso comum, o que por consequência lhe faz ser convencionalmente acatada a partir de ações educacionais "conscientes, racionais e bem intencionadas".

A trajetória percorrida por Apple estabelece enquanto meta, ante a necessidade pela compreensão acerca do papel curricular enquanto legitimador do conhecimento oficial, o despertar de um exame crítico, por parte dos educadores, sobre o efeito das ações do currículo para com as relações sociais, o que possibilita enxergar como a conjuntura científica, política, ética, moral, pedagógica e natural, constitutivas das ações humanas, passa a ser influenciada a partir de tal efeito. Ao especular acerca de uma abordagem capacitada à solidificação dessa empreitada, este autor busca não cometer o mesmo equívoco de análises anteriores, ao se restringirem exclusivamente ao controle e determinação da esfera econômica sobre o currículo e o processo de escolarização. Esclarece que, ao mesmo tempo em que crítico, este exame sobre o efeito da educação formal deve estar exclusivamente comprometido com indagações no campo da esfera cultural, e não somente alcançar o que tange a esfera econômica (APPLE, 2005).

A naturalização de uma legitimidade ao que é ensinado no ambiente escolar passa a ser alvo de reflexão aos estudos sobre currículo. No imo de suas análises, Apple, em "Ideologia 
e Currículo" busca compreender as relações estabelecidas entre cultura e economia, assim como o modus operandi do papel ideológico, à vista da instituição escolar. O rigor de sua análise possibilita uma reflexão ampla tanto acerca das formas e dos conteúdos acatados em preferência pelo currículo, das relações sociais imbuídas ao ambiente da sala de aula, como também dos valores e conceitos dados pelos educadores a estas formas e conteúdos, que na configuração de senso comum é expressão cultural máxima de um determinado grupo, num determinado contexto histórico. Em outras palavras passa a existir uma investida, no campo do estudo curricular, à percepção das instituições educacionais enquanto intercessoras das ideologias e dos conhecimentos que operam no esteio das relações sociais (APPLE, 2005).

O que excepcionalmente difere o status operante dado a estas instituições nas análises levantadas por Apple (2005), no decorrer da obra em questão, parte do entendimento que as instituições educacionais, para além da distribuição, atuam também na lógica da produção de valores ideológicos e conhecimentos legitimamente consagrados, ou seja, tal qual a produção de uma mercadoria, as instituições também confeccionam em favor da demanda pela legitimação e distribuição de conhecimentos e valores corroborativos para coma a conservação de um poder econômico e cultural dominante.

A relação estabelecida entre a sociedade, sobretudo quando se considera a abrangência de suas relações de desigualdade, com os valores e conhecimentos oficiais anteriormente referidos, incentivados e desenvolvidos no interior da escola a partir de uma lógica de produção/distribuição, faz com que haja constante contradição entre os objetivos e os resultados ensejados e colhidos no contexto da escola. A demanda conservadora, sistematizada e orientada às vias da pressão que exercem os grupos dominantes sobre a naturalização, cada vez mais intensa, e a aproximação ao senso comum das informações contidas em sua própria esfera cultural, busca fertilizar o pressuposto ideológico desses grupos, desqualificando todo e qualquer valor que não compactue à manutenção de seu estado de hegemonia (APPLE, 2005).

Apple (2005, p. 47) salienta que apesar do eixo central das formulações contidas em "Ideologia e Currículo" pautarem-se acerca da expressividade das forças de reprodução ideológica no contexto escolar, esta obra não menospreza a prospectiva de um estado de renitência, uma vez que também favorece reflexões acerca das chamadas "tendências contraditórias, resistências e conflitos" com relação ao papel ideológico assolador da conjura pela qual operam os interesses dominantes. Tal prospectiva, que se evidencia sobremaneira em obras posteriores, como "Educação e Poder" e "Teachers and Texts", será apresentada em sequência à ênfase dada à questão da relação estabelecida entre currículo e reprodução ideológica.

Para Michael Apple o currículo se encontra diretamente relacionado às esferas econômica, cultural e política, portanto não é neutro, inocente e muito menos desinteressado de conhecimentos. Em contrariedade este deve ser adjetivado enquanto determinado, ardiloso e dotado de um conhecimento minuciosamente selecionado. "A seleção [de conhecimentos] que constitui o currículo é o resultado de um processo que reflete os interesses particulares das classes e grupos dominantes" (SILVA, 2017, p. 46). A abrangência da relação estabelecida entre currículo e reprodução ideológica não busca a compreensão da 
legitimidade dada ao conhecimento, mas a consideração dada à legitimidade deste conhecimento, ou seja, a reflexão vale-se da configuração segundo a qual há consideração de legitimidade a determinados valores e conhecimentos em detrimento a outros, enquadrados enquanto ilegítimos e não oficiais. Silva (2017, p. 47) salienta que a prerrogativa de Apple busca esmiuçar a razão acerca da legitimidade dada ao currículo. Razão esta que se acobertava ante a neutralidade metodológica adotada por análises antecedentes.

Na perspectiva de Apple, a questão importante é [...] a do "por quê". Por que esses conhecimentos e não outros? Por que esse conhecimento é considerado importante e não outros? E para evitar que esse "por que" seja respondido simplesmente por critérios de verdade e falsidade, é extremamente importante perguntar: "trata-se do conhecimento de quem?". Quais interesses guiaram a seleção desse conhecimento particular? Quais são as relações de poder envolvidas no processo de seleção que resultou nesse currículo particular?

A compreensão sobre o funcionamento do sistema capitalista, a partir das esferas econômica e cultural, é do ponto de vista de Apple (1997), o pontapé inicial para o estabelecimento de um posicionamento reivindicatório em desfavor à política do conhecimento oficial, ou seja, o local propício para o nascimento de contrafogo a configuração que dá legitimidade aos valores e saberes constituintes do currículo oficial. As pistas dadas ao funcionamento deste sistema, ainda na introdução acerca da política do conhecimento oficial, relacionam as esferas cultural e econômica a uma lógica de mensuração acerca do quanto um determinado objeto/indivíduo contribui para a produção de riqueza, independentemente da via de mensuração desta produção (capital cultural ou do capital econômico). Tal lógica de mensuração faz da condenação moral um fator natural à parcela fracassada da sociedade, que no intento e almejo pela produção de riqueza, acaba de alguma forma se desfavorecendo.

Ao ser apreendida enquanto natural esta condenação moral a determinado estrato/parcela da sociedade, passa a existir também uma aceitação social acerca das relações de exploração. O esteio desta naturalização, aos tempos de "Ideologia e Currículo", valia-se das políticas sociais, ao passo em que estas se submetiam às rédeas do estado liberal. Em reafirmação de seu posicionamento, Apple (2005) evidencia que com a coalização da direita, estas políticas vêm sofrendo constantes ataques, uma vez que passam a requerer uma condição consensual ante os diferentes (e até conflitantes) novos argumentos dos seguintes conluios da direita: "neoconservadores, [...] agentes da modernização econômica [...] e recém-formados grupos de direita" (p. 48).

Essa conjuntura é caracterizada por Apple (2005) enquanto alarmante às políticas e direitos sociais do estado liberal, que passam a ceder espaço à emersão de uma nova estratégia de enfrentamento às imposições e premências da sociedade. Cuidadosamente estudada, esta nova estratégia, enquanto alvo de consenso dos interesses que outorgam os recém-formados conluios da direita, agora passa a conciliar uma espécie de "política populista" com a "ética de livre mercado". Dessa conciliação é possível evidenciar quatro resultados imediatos, que 
ao operarem sobre as esferas política, econômica e cultural, passam também a repercutir no campo educacional, especificamente sobre a lógica de legitimidade dada aos valores e conhecimentos constituintes do currículo oficial.

Eis os resultados: parcial desmantelamento das políticas sociais-democráticas que beneficiaram amplamente a classe trabalhadora, as pessoas de cor e as mulheres (grupos esses obviamente não-excludentes entre si); estreitamento de relações entre governo e economia capitalista; radical enfraquecimento das instituições e do poder da democracia política; e tentativas de cerceamento de liberdades adquiridas no passado (APPLE, 2005, p. 48 e 49).

A consequência da estratégia içada pelo "populismo autoritário" é desastrosa, pois passa a inferir contraditoriamente às imposições e premências da sociedade. Este fato favorece o surgimento de um sentimento de reconciliação, por parte do conluio conservador da direita, para com a posição social-democrática, dita "liberal". A recriminação de Apple busca apontar, todavia, para as fragilidades emergidas a partir da reconciliação entre "populismo autoritário" e o posicionamento social-democrático "liberal". Para tanto, este autor recorre ao campo educacional a fim de ponderar acerca do eloquente almejo pelo status hegemônico, por parte da postura estabelecida entre os conluios conservadores da direita.

Em tempos onde tais conluios se projetam enquanto ditadores de sentido ao contexto educacional, a soberania dada à política do conhecimento oficial torna-se explícita. Michael Apple, ao se dedicar à compreensão dos artifícios desta política, passa a reconhecer que sua posição de soberania depende exclusivamente da projeção de seu poder de convencimento. Este poder projeta-se a uma parcela da sociedade que atribui a um objetivo errôneo o status de "primordial" à educação. A primordialidade deste objetivo, contudo, equivocadamente se articula às necessidades mercadológicas, o que permite revelar seu fiel sentido dado a política do conhecimento oficial, assim como a lógica furtiva com que esta política legitima determinados valores em prol da manutenção do status hegemônico dos conluios conservadores da direita (APPLE, 1997).

A legitimação de valores que corroboram para com a política do conhecimento oficial, ao que concernem as discussões científicas no campo educacional, encontra forças no paradigma epistemológico imperante. Reconhecido enquanto "tradição do rendimento", essas discussões negligenciam a possibilidade de análise aprofundada acerca das complexidades constitutivas do cotidiano da escola. A ênfase positivista dada a este modelo, como também o estabelecimento de um foco orientado ao resultado, o torna incapacitado à elaboração de reflexões que cerceiem, em grau de amplitude, o contexto político, econômico e ideológico das instituições escolares. "As escolas repousam isoladas da sociedade estruturalmente desigual (e dos conflitos que isto engendra) da qual elas são parte" (APPLE e WEIS, 1986, p. 19).

O "repouso da escola", como Apple e Weis (1986) denominam o contexto caracterizado pela "tradição do rendimento", emerge do descaso, por parte dos educadores, para com um enfoque científico que trace intersecções, a partir de investigações amplas, entre a as práticas 
do cotidiano escolar e o desdobramento destas nas relações sociais. Esta incapacidade vivifica a ideia de adormecimento das lúcidas interpretações acerca do ambiente escolar, tendo em vista que a intensa necessidade de maximização do rendimento acadêmico impede o despertar de respostas a questionamentos que respaldariam interpretações sociais, culturais e estruturais acerca deste ambiente, tais como: "O que é que a educação faz no contexto mais amplo? Quando ela faz isso, quem se beneficia?” (p. 20).

A lógica inerente à "tradição do rendimento", assim como a desqualificação científica caracterizadora do "repouso da escola" são características influentes à política do conhecimento oficial, pois suportam os objetivos expressivos contidos naquele projeto educacional anteriormente exposto, que se frutifica a partir de um consenso entre os conluios conservadores da direita. Estes conluios, portanto, via currículo, impulsionam a legitimação e produção de um conhecimento oficial baseado em valores culturais que incentivam a lógica de acumulação de riquezas. Este impulso é condição primordial à manutenção do status hegemônico destes conluios, pois lhes possibilita, através do incentivo à mobilidade social, uma contínua amplificação de poderio sobre a arena social (APPLE, 1997).

Ao retratarem o que revela o restrito número de pesquisas preocupadas em analisar o papel econômico, ideológico e social do aparato educacional, Apple e Weis (1986) apontam três atividades que fundamentalmente caracterizam o papel da escola, a saber: o auxílio na acumulação, na produção e legitimação.

A primeira destas atividades pressupõe ser, a escola, um ambiente passível de fornecimento das condições caracterizadoras da desigualdade econômica, consequentemente do modo de acumulação capitalista. A evidência deste processo está, para ambos os autores, no modo como a escola seleciona e distribui, sob a égide de princípios meritocráticos, os próprios estudantes que por ela transitam. A meritocracia aqui pensada impulsiona uma espécie de ordenamento hierárquico entre os estudantes, conformando uma segregação entre os mesmos. "Desta forma, as escolas ajudam a atender as necessidades que tem a economia de um corpo de empregados estratificado e ao menos parcialmente socializado" (APPLE e WEIS, 1986, p. 20), o que culturalmente favorece os conluios dominantes e conservadores da direita.

É necessário ter cautela sobre a influência exercida pela escola com relação ao processo de acumulação. Enxergar a ação educacional enquanto limitada à necessidade da esfera econômica pela divisão do trabalho, como anteriormente afirmado (APPLE, 2006), é usufruir de uma visão reducionista acerca da mesma. É necessário, em contrapartida, também dar atenção às demais esferas com as quais o aparato educacional encontra-se atrelado. As duas outras atividades evidenciadas por Apple e Weis (1986) auxiliam sobre a evidência de tal necessidade.

A atividade de legitimação, segunda característica do papel escolar elencada por esses autores, considera a escola uma ferramenta de seguridade às ideologias culturais e sociais dos grupos sociais hegemônicos (ou ideologia dominante). O papel ideológico, à vista da ótica gramsciana, enfatiza uma ação subversiva a atividade de legitimação da escola. Entretanto por se tratar de uma ferramenta de expressão de hegemonia, esta mesma ideologia pode também pressupor uma ação de consentimento, por parte de um grupo subjugado, a 
serviço de uma ação de poder, por parte de um grupo hegemônico, o que favorece o estabelecimento de domínio ao grupo promotor da segunda ação. A ação de consentimento do grupo subjugado, no interior da escola, revela-se favorável à "tradição do rendimento", assim como à meritocracia enquanto principio de funcionamento das relações sociais.

Uma verdade aparente é edificada em função do estabelecimento da lógica meritocrática como princípio regimentar das relações internas ao contexto escolar. A escola passa a ser compreendida como suposta instituição favorável à igualdade social, e continuamente direcionada à justiça econômica e social. Evidente é a necessidade de contestação a este direcionamento equivocado acerca do papel escolar, que em forma de senso comum passa a se caracterizar enquanto expressão cultural máxima.

Na contramão desta orientação ilusória, a legitimação que se afirma ao contexto escolar, ante a necessidade de constatação dos valores considerados adequados ao currículo oficial, não responde de forma igual às distintas classes, raças, sexos, e demais classificações sociais. Apple e Weis (1986) evidenciam, a partir do respaldo científico ofertado por pesquisas desenvolvidas no campo da educação, uma verdadeira situação de desigualdade a respeito do destoante número de pessoas que efetivamente se beneficia das políticas de educação, em detrimento do número de pessoas não beneficiárias.

A terceira característica, ao que refere o estudo do papel escolar desenvolvido por ambos os autores, diz respeito a produção. Apple e Weis (1986), antes de se empenharem às reflexões sobre especificidades concebidas a esta característica, entretanto, salientam três elementos que a possibilitam situar enquanto alvo de destaque no campo das reflexões educacionais: o primeiro elemento diz respeito ao notório saber técnico-administrativo ${ }^{3}$, incremento da lógica de produção, distribuição e consumo, admitida pelo arranjo capitalista; em consonância ao saber técnico-administrativo, outro elemento segundo o qual a característica produtiva do papel escolar se firma, diz respeito à inovação tecnológica.

Estes dois elementos, em prol do caráter produtivo da escola, intimamente se relacionam. À vista de interesses comuns passam a corroborar para com a política do conhecimento oficial, na medida em que, essencialmente, estão incluídos nesta pleno acato aos saberes técnicos e desenvolvimento/conhecimento tecnológico arrojado. Para além, entretanto, do conhecimento técnico-administrativo e da inovação tecnológica, outro aspecto soma à característica produtiva do papel escolar: o controle cultural (APPLE e WEIS, 1986). A máxima deste controle se mostra aparente nas posturas conservadoras em prol da elucidação de uma cultura comum entre os escolares. O que de fato acontece, em virtude desta postura, é uma estratégia de apaziguamento das forças - que se mostram ameaças - ao poder hegemônico alcançado pelos conluios conservadores. Contraditoriamente, a ideia de cultura comum pode ser entendida enquanto ponto de partida para a formulação de um consenso político e cultural entre esses grupos. Este consenso, todavia, baseia-se nos valores de um grupo hegemônico, que detém o poder de exercício e avaliação acerca da legitimidade do próprio conhecimento disposto no currículo oficial. Apple (2005, p. 50), sobre o entendimento de cultura comum, torna clara sua opinião: 
O atual apelo de "retorno" a uma "cultura comum", na qual os valores de determinado grupo - geralmente o grupo dominante - são transmitidos a todos os alunos, nada tem a ver, em minha opinião, com uma cultura verdadeiramente comum. Trata-se de uma abordagem por demais superficial, que mal toca nas questões políticas em pauta. Uma cultura comum jamais poderá ser a disseminação geral, para todas as pessoas, daquilo que uma minoria pensa e acredita. Ela requer não a imposição de padrões e conceitos, que nos tornem a todos "culturalmente letrados", mas sim, e essencialmente, a criação das condições necessárias para que todas as pessoas participem da formulação $e$ reformulação de conceitos e valores.

A proposta de cultura comum, enfática projeção dos conluios conservadores da direita para com a alegação de um conhecimento oficial, exemplifica a necessidade de reconciliação, enquanto estratégia de reafirmação de poder, à política social-democrática "liberal". Aqui se apresenta enquanto verdade aparente, como anteriormente mencionado, o caráter socialdemocrático, a vista de que tanto aliado à "tradição do rendimento", quanto acobertado pela meritocracia enquanto princípio de funcionamento das relações sociais, este torna conciso a imposições de padrões determinantes e favoráveis à promulgação de uma cultura comum. Vê-se um tipo de "peseudo-social-democracia", que não considera a participação coletiva nas deliberações acerca dos elementos (conceitos e valores) fundamentais que substanciam a prospectiva de uma cultura comum (APPLE, 2005).

O controle cultural, junto ao conhecimento técnico-administrativo e a inovação tecnológica, fomenta a terceira característica do papel escolar, ou seja, a produção do conhecimento oficial. As universidades, sobretudo, destacam-se enquanto fontes de produção deste conhecimento, pois além de desenvolverem pesquisas relacionadas à efetividade de diversas estratégias para utilização deste conhecimento técnico-administrativo, funcionam enquanto campo de treinamento/recrutamento de futuros-empregados capacitados ao exercício profissional em moldes do nivelamento técnico apurado pelo mundo do trabalho.

É preciso tornar também evidente, para além da investida dada à análise das forças de reprodução ideológica, vinculadas à oficialização de um conhecimento que se mostra favorável aos valores políticos, econômicos e culturais dos grupos dominantes, o reconhecimento pelo trabalho contra-hegemônico almejado por Michael Apple. Este autor deixa claro que a reprodução econômica e cultural, nem de longe, deve ser entendida enquanto único fenômeno caracterizante do processo educacional, para tanto evidencia a existência das chamadas "tendências contraditórias, resistências e conflitos em torno dessas forças ideológicas” (APPLE, 2005, p. 47). Tendências estas fundamentais para a edificação de um posicionamento contra-hegemônico aos interesses materiais e ideológicos dos conluios conservadores da direita. De extrema relevância é, para este posicionamento, aterse a respeito de como estes conluios operam sobre as condições de atuação no campo educacional, pois tendo conhecimento acerca das estratégias e manobras porvindouras desta atuação - sobretudo das contradições emergidas destas manobras - é que a realidade se torna passível a alteração. 
"Devemos sempre lembrar [...] que a nova direita enfrenta contradições que ela não apenas não reconhece, mas que não pode facilmente resolver" (APPLE, 1997, p. 17). Isso oportuniza a afirmação argumentativa, criticamente fundamentada, àqueles que se opõem às audazes estratégias e manobras alçadas pelo consenso entre os conluios conservadores da direita (ou simplesmente nova direta, como Apple prefere denominar). As boas intenções dos oposicionistas às tendências hegemônicas podem promover dúvidas àqueles que não conseguem compreender a real importância de se manter acesa a chama de uma consciência encorajada pelo contrafogo às incessantes degradações promovidas pela nova direita, durante a corrida pela supremacia de seus valores e seu conhecimento oficial.

Os que se opõem aos ideais da nova direita abstraem a singular importância conferida ao poder da crítica, qual seja: a afirmação, a reivindicação e o caráter cidadão. "A crítica é, então um dos mais valiosos instrumentos que temos para demonstrar que esperamos mais do que promessas retóricas e sonhos desfeitos, porque tomamos certas promessas seriamente" (APPLE, 1997, p. 18). Em tempos onde a sociedade se caracteriza pela imediata naturalização da condenação moral, assim como pela constante aceitação das relações de exploração, Apple (1997) encontra no posicionamento crítico uma possibilidade de alavancar a reivindicação contra-hegemônica. A criticidade se relaciona, sobretudo, à compreensão acerca dos desvelamentos históricos que levaram a sociedade a se enquadrar a estas características. Recorrer à história, portanto, significa possibilitar a reconstrução dos acontecimentos que tornaram hegemônicos os interesses materiais e ideológicos da nova direita, significa projetar expressivas análises acerca das relações de poder que operam sobre os diferentes setores da sociedade (vale destaque ao educacional), em virtude da supremacia de valores econômicos, políticos e culturais.

Uma expressiva análise de poder, aos olhos de Apple (1997), constitutiva da crítica que leve em conta a relevância histórica para a compreensão da realidade, permite desnudar os engendramentos da política do conhecimento oficial, ou seja, compreender como esta passa historicamente a se configurar enquanto promotora de relações conflituosas, onde a atenção dada aos interesses culturais e políticos, cada vez mais, passa a ser meta reivindicativa entre os grupos que cogitam o status de hegemonia.

Michael Apple confere extrema relevância ao reconhecimento, para os críticos que reivindicam/lutam pela afirmação de valores das parcelas sociais desfavorecidas, das próprias estratégias utilizadas pelos conluios conservadores da direta. Posicionamentos como este vêm, dentre as produções deste autor, cada vez mais ganhando força, sobretudo na última década, onde tem se dedicado a apresentação de contrárias alternativas, no contexto educacional de vários países, ao rumo tomado pelas políticas neoliberais. Sobre a necessidade de se pensar a educação enquanto transformação social, em sua mais recente obra, Apple (2017, p. 251) elucida alguns cuidados a serem tomados pelo posicionamento contrahegemônico:

[...] Precisamos definidamente ser apropriadamente críticos sobre o poder de destruição da restruturação neoliberal e da comodificação de tudo o que nos importa [...]. Precisamos definitivamente reagir contra um sistema econômico e 
seu conjunto cultural e ideológico que cria as condições que fazem com que pareçam razoáveis e factíveis. Porém, ao mesmo tempo, também precisamos reconhecer os efeitos destrutivos, mas ainda relativamente autônomos dessas outras relações de dominação e subordinação dentro e fora da educação (grifos meus).

A este ponto vale ressaltar, em Apple (2006), que a escola não é simples interpretação reprodutiva da sociedade, e que é inverdade dizer que unicamente se dedica a moldar seus estudantes, de forma passiva, para a vida em uma sociedade desigual. Compactuar com este pensamento é acordar à neutralidade metodológica do currículo, é dar pouca significância à esfera cultural e, por consequência, abster-se de um posicionamento contra-hegemônico que enxergue tal esfera como ferramenta também comum aos grupos sociais subalternos, isto é, passível de ser constituída e apropriada por parte destes grupos, e tão logo deixar de ser vista como restrita a um processo de mercantilização e acumulação (APPLE, 1989). "[...] Se tudo que fazemos como educadores críticos [...] for apenas valorizado pelos seus efeitos na economia, isso limita drasticamente o que significa reagir lutando contra o que está acontecendo com tantas pessoas" (APPLE, 2017, p. 251 e 252).

A noção de que ocorre, na arena educacional, um processo mecânico de reprodução dos valores considerados adequados a desigual distribuição que caracteriza o sistema econômico vigente, deve ser analisada a fundo quando especulada uma posição contra-hegemônica. Não deve ser posto enquanto regra a suposição de que a correspondência existente entre as empresas, que constantemente necessitam de trabalhadores com valores culturais e ideológicos adequados, e as escolas, que enfaticamente têm como um de seus papéis a produção em massa deste trabalhador, seja sempre exitosa. O estudante que se caracteriza a partir do baixo status de ajustamento, de acordo com a lógica de orientação oferecida pela estratificação social, ou seja, pertencente a uma classe social baixa, não necessariamente precisa ser visto à mercê de um currículo que lhe incite reprodução das relações sociais.

A necessidade de a esfera cultural ser interpretada enquanto ferramenta subalterna, do ponto de vista de um posicionamento contra-hegemônico, pode romper com a inquestionável lógica de imposição de valores e ideologias hegemônicas, assim como pode transcender a lógica dada ao processo mecânico de reprodução existente entre o papel escolar produtivo e as necessidades do mercado de trabalho (APPLE, 1989). A objetivação da cultura assim pensada auxilia na transposição da percepção da escola apenas enquanto mecanismo de reprodução das relações de classe existentes na sociedade, ou seja, extrapola as influentes especulações das teorias da correspondência, que tanto corroboram para com a "tradição do rendimento", e da mesma forma à desqualificação científica que caracteriza o "repouso da escola".

Apple (1989, p. 84) destaca uma consequência negativa ao buscar compreender, do ponto de vista das teorias da correspondência, o papel da escola, qual seja: a impossibilidade de surgir, sob influência do pessimismo que urge da interpretação destas teorias, uma ação educativa consciente e determinada, que se sensibilize ao enaltecimento da voz dos subalternos. Seu posicionamento de contrariedade às teorias da correspondência o permite 
estruturar nortes elucidativos acerca da cultura enquanto representação dos grupos subalternos. Ao discorrer sobre os "modos de determinação", passa a compreender a relação firmada entre instituições sociais e forças socioeconômicas enquanto dialética, e não unicamente reprodutiva. Um olhar atento aos "modos de determinação", portanto, implica numa percepção acerca das contradições e limitações que estruturam a sociedade. Este é o ponto de partida para o posicionamento contra-hegemônico de uma teoria curricular, qual seja: perceber as contradições e limitações que estruturam as relações entre forças socioeconômicas e instituições sociais e, em concomitância a isto, contra-atacar as medíocres teorias da correspondência, que naturalmente se apresentam, no contexto educacional, enquanto senso comum, e abre brechas à "tradição do rendimento" e ao "repouso da escola".

A aproximação da cultura enquanto ferramenta subalterna, no contexto educacional, portanto, deve somar à metáfora da reprodução advinda das simplistas afirmativas da teoria da correspondência. Essa soma acontece a partir da inserção de outros modos de determinação, tal como exemplificado por Apple (1989) durante sua apreciação da organização e do controle real de um processo de trabalho desenvolvido por homens e mulheres que ostensiva e informalmente se encontram envolvidos em suas atividades. A organização e controle real do processo impossibilitam se pensar as atividades destes trabalhadores somente em termos reprodutivos, pois nos exemplos ${ }^{4}$ dados o trabalho não sugere ser controlado por preceitos ideológicos, técnicos e administrativos do modo de produção capitalista, ou seja, o trabalho não se configura a partir das exigências deste modo de produção - rigidez estrutural, autoridade, pontualidade, obediência etc. -, mas enquanto uma complexa e verdadeira "cultura do trabalho".

Apple (1989, p. 97) evidencia a cultura do trabalho enquanto propiciadora de "elementos importantes para a resistência do trabalhador, para a ação coletiva, para o controle informal da cadência e das destrezas e para a reafirmação de sua própria humanidade". Evidencia-se aqui um potencial, ou um modo de determinação, intrinsicamente vinculado à ação do trabalho: o potencial transformativo. A organização e o controle real do trabalho, perante o modo de produção capitalista, não podem deixar de serem compreendidos, à vista de um posicionamento contra-hegemônico, sem levar em consideração os esforços de resistência, construídos pelos trabalhadores envolvidos no processo, ao controle que enfaticamente lhes é exercida. Apple (1989, p. 102), continua: "Se fui correto na minha análise, que em quase toda situação real de trabalho, haverá elementos de contradição, de resistência, de autonomia relativa, que têm potencial transformativo, então o mesmo vale para as escolas".

O potencial transformativo é a esperança de Apple (2002) para com a interrupção daquele ponto de vista cunhado pela nova direita conservadora, que enfaticamente se consolida a partir das teorias da correspondência, assim como projeta constantes especulações acerca da percepção de cultura pelo viés da mercantilização, e não enquanto representação dos grupos sociais subalternos. A cultura do trabalho, elucidada em "Educação e Poder", apresenta-se enquanto uma alternativa visível, para os educadores, ao aliarem propósitos educativos a uma educação política e consciente (APPLE, 1989). A aproximação entre trabalho educacional e arena político-econômica, do ponto de vista do autor, é um passo em favor da erradicação das estratégias neoliberais ao ambiente escolar (APPLE, 2002). A 
consciência empregada por tal ação educativa e política, se encontra na superação da "tradição seletiva", que por sua vez se alimenta do desprezo a importantes heranças históricas de movimentos e segmentos da população subalterna, inviabilizando-a, na atualidade, do acesso ao conhecimento histórico acerca de seus próprios esforços de resistência e lutas, cunhados a partir de relevante pertinácia e encontrados às vias do esquecimento.

Se podemos encontrar resistências, se mesmo apenas num nível informal podemos encontrar homens e mulheres em nossas empresas, fábricas e em outros locais lutando para manter seus conhecimentos, humanidade e dignidade, então a ação curricular pode ser mais importante do que imaginamos. Pois os estudantes necessitam ver a história e a legitimidade dessas luta. O ensino da história séria do trabalho, organizado em torno das normas de oposição produzidas por homens e mulheres que resistiram [...], pode constituir uma estratégia efetiva para a ação educacional (APPLE, 1989, p. 102, grifo meu).

A ação educacional deve, em função da "cultura do trabalho", cunhada pela organização e controle do processo de trabalho - em contrafogo à análise das teorias da correspondência via reprodução, ou seja, adverso, do ponto de vista de um posicionamento crítico, a este uno e errôneo modo de determinação -, tornar acessível o conhecimento histórico ao mesmo tempo em que prioriza o questionamento do sistema de conceitos e valores recorrentes à sociedade. Sistema este que, por se caracterizar pela ganância, acumulação, egoísmo e alienação, assim como por passar a ofertar um caráter ético à lógica da privatização, por exemplo, deve ser, num contexto pedagógico sensibilizado ao posicionamento contrahegemônico, minimamente alvo de dezenas de dúvidas e retaliações.

Os valores recorrentes desta sociedade coadunam com a "tradição seletiva" anteriormente elucidada, que para a composição dos currículos atuais se vale de materiais que dão pouca (ou nenhuma) significância à história, que desprezam importantes aspectos que constituíram ganhos relevantes para determinados grupos e segmentos da sociedade. A "tradição seletiva" destes materiais que formam o currículo, desta forma, acaba por censurar, por exemplo, relevantes aspectos do movimento operário, em favor de um perfil considerado justo à atividade trabalhista hodierna, de um estereótipo em conformidade aos valores recorrentes da sociedade (APPLE, 1989). É emergente a ação contra-hegemônica de um trabalho educacional que opere na contramão desta "tradição seletiva": essa ação é consolidada por um potencial transformativo que exalta a voz dos subalternos, na medida em que reafirma a relevância histórica dada às suas conquistas. Desta forma propicia, em prol da conscientização coletiva pela reivindicação contra-hegemônica, aproximação e, consequente problematização, dos materiais que constituem o currículo ante os temas sócio-políticos que historicamente se apresentam em desfavor à exaltação das vozes das camadas desfavorecidas. Apple (2002, p. 96) frisa que

[...] precisamos [enquanto educadores conscientes da necessidade de uma ação contra-hegemônica] ser muito mais activos na tentativa de dar respostas a professores, a membros da comunidade e a um público cada vez mais céptico que 
se interroga sobre questões como "o que vou eu ensinar?", "como vou ensinar?", "como vou avaliar o meu ensino?" - trata-se, basicamente, de um conjunto de questões práticas que todas as pessoas têm o direito de colocar e para as quais têm o direito de obter respostas razoáveis. À falta disto, ficamos à margem enquanto a direita reconstrói não só o senso comum mas também as escolas que ajudam a produzi-lo.

A ação educacional não pode deixar de almejar a "cultura do trabalho", somente assim não se restringe à formalidade contida nas teorias da correspondência, e por consequência não se limita à "tradição seletiva", que passa a ofertá-la uma orientação mercantil. A elucidação da ação educacional pela cultura do trabalho corresponde a um intuito educacional e político que, ao se ater aos modos de determinação do próprio ambiente educativo, se capacita à aproximação dos elementos ativos da cultura e do trabalho, esclarecendo as limitações e contradições estruturais deste sistema ao mesmo tempo em que promove o florescimento de ações contra-hegemônicas.

Se os modos de determinação do ambiente educativo possibilitam esclarecimento acerca de suas contradições e limitações, estratégias de transformações que se aproveitem deste entendimento para a fundamentação de críticas e retaliações a este ambiente, na prospectiva de reestruturá-lo, são passíveis de aparecimento. A crítica ao discurso dos conluios conservadores da direita a partir de suas reformas que buscam elucidar o caráter democrático, e consequentemente o "favorecimento" dos subalternos, deve ser veemente. "Elas [as críticas] podem levar o crescimento de instituições alternativas, [...] que podem ajudar no desenvolvimento de modelos socialistas interessantes e viáveis de arranjos pedagógicos e curriculares. Essa possibilidade não poder ser levianamente descartada" (APPLE, 1989, p. 145).

O planejamento, construção e administração destas instituições, que se formam perante a brecha oportunizada pelo posicionamento contra-hegemônico à política do conhecimento oficial e suas constantes reformas (enfaticamente "democráticas"), deve alçar o verdadeiro sentido da democracia, respaldando-se em conhecimento econômico, político e organizacional necessário para o correto favorecimento de grupos subalternos historicamente desprestigiados, e não mascarar esta necessidade a partir de reformas (de "vales educacionais", nas palavras de Apple) a estes grupos.

A avaliação e, por consequência, o desmascaramento das reformas do Estado liberal, caracteriza-se enquanto uma estratégia oportuna a favor dos grupos subalternos, pois os permitem constituírem e controlarem instituições econômicas e culturais, a partir do desenvolvimento de habilidades organizacionais, que lhes conferem dignidade e exaltação da própria voz.

[...] precisamos ver a luta para criar instituições econômicas e culturais mais justas como uma guerra de posição, como uma luta numa variedade de frentes. Uma dessas frentes é certamente a educação. Se o estado - por causa de sua crise econômica e de sua própria crise de legitimidade das forças em competição no seu interior e da realidade do que está reservado para os jovens da classe 
trabalhadores - oferece possibilidades de intervenções socialistas democráticas, então devemos aproveitá-las. Entretanto, [...] aproveitá-las não é uma coisa assim tão simples. Essa pode ser uma daquelas ocasiões em que tenhamos de examinar os dentes do cavalo que nos estão presenteando (APPLE, 1989, p. 146 e 147, grifo meu).

A luta que Apple (1989) faz menção certamente é de substancial importância, e tem como uma de suas frentes (talvez a principal) a educação. Suas investidas devem partir da brecha sugerida pelas contradições e limitações de sentidos advindos das ações do aparelho estatal, todavia para que tais contradições e limitações estruturais sejam percebidas, faz-se necessário conhecimento acerca dos modos de determinação que assinalam as relações entre forças socioeconômicas e instituições sociais. O conhecimento acerca destes modos de determinação é condição primeira para a instauração da luta reivindicada por Apple. Esses conhecimentos carecem de sentido se não vinculados à abrangência de um discernimento histórico acerca dos esforços de resistência, lutas e conquistas dos subalternos, como também da reivindicação de seus direitos ante a negação e desprestígio que lhes vem sendo historicamente concebidos.

O posicionamento contra-hegemônico, em prol da materialização do estado de luta dos subalternos, caracteriza-se pela cautela. Apple (1989) permite, fazendo contrária alusão ao provérbio "a cavalo dado não se olha os dentes", compreender a cautela com que a possibilidade de confronto às deliberações do Estado deve ser efetivada. Ter minúcia significa consolidar um potencial transformativo a favor de uma conscientização coletiva favorável à problematização da configuração/legitimação curricular oficial. Tal problematização é substanciada pelos modos de determinação, assim como pela possibilidade, fenecida por esses, para se enxergar as contradições e limitações das relações socioeconômicas e instituições sociais. Como consequência da problematização, esta minúcia também significa aptidão à instauração de novas instituições culturais e econômicas que consubstanciem e cabalem a favor das reivindicações dos grupos sociais subalternos.

\section{Considerações finais}

Se para o bloco humanista, destarte, o currículo toma como ponto de partida a análise de "experiências vividas" (ou da multiplicidade delas, na medida em que se alia aos pressupostos hermenêuticos) e, diante disto, cogita a transposição de "conceitos teóricos" e "abstrações" historicamente cultivados e reiteradamente enfatizados pelas teorias tradicionais do currículo - e conseguintemente toma forma de ferramenta de emancipação dos grupos sociais subalternos -, para o bloco marxista a noção de "experiências individuais" carrega consigo contradições que impossibilitam as perspectivas teóricas do currículo alinhadas ao pensamento humanista se autoproclamarem "críticas": a compreensão do percurso formativo de um indivíduo, tal como valoriza o método curare, abstraído de toda "leviandade" contida na consolidação natural das atividades cotidianas, contradiz-se ao passo 
em que se abstém do estabelecimento de juízos de valores sobre as relações desiguais entremeadas às distintas "experiências vividas".

Ao tentar se esquivar da "consolidação natural das atividades cotidianas" esquece-se de estranhar a naturalidade nelas contida ${ }^{5}$, sugerindo a própria naturalização das relações desiguais que se colocam entre as muitas "experiências individuais".

Do contrário, a necessidade de materialização do estado de luta é a finalidade contrahegemônica disposta por Michael Apple para a elucidação de uma teoria crítica acerca do papel curricular. Este autor revoluciona o campo de estudo acerca do currículo ao se dedicar à análise do componente educacional levando em conta o papel deste na produção do conhecimento técnico a uma parcela de indivíduos, na legitimação deste conhecimento sob a égide de princípios e valores representativos do status de "normalidade" e "desvio", na utilização constante destes conhecimentos a partir de um ordenamento hierárquico, com respaldo da meritocracia na condição de princípio de funcionamento das relações sociais, que fomenta a lógica de acumulação.

As reflexões deste autor desencadearam novas especulações acerca do papel curricular. Em síntese passam a favorecer uma leitura crítica da apresentação da realidade do contexto escolar e das relações sociais capitalistas. Pensa, tão logo, o currículo a partir de uma análise relacional, ou seja, elucidando, com base nas relações estabelecidas entre as forças socioeconômicas e as instituições sociais (incluindo a escola), assim como no modo de organização e controle estabelecido por essas relações, tanto na esfera econômica, quanto ideológica e política, o processo beneficiário de alguns grupos e classes em detrimentos a outros, cunhados subalternos. Apregoam também, as reflexões sugeridas por este autor, sobre a capital necessidade de expressão das vozes destes grupos e classes subalternos, para esse fim se alia a uma concepção socialista e democrática de se pensar os arranjos pedagógicos e curriculares, conferindo-lhes uma importante atribuição para a ascensão de uma sensibilização coletiva, como também para a revelação de um estado de luta subalterno contra o modo de administração dos conluios conservadores da direita.

\section{Notas}

1. “Apresenta-se como obra inédita no Brasil, adotando a fenomenologia no tratamento do currículo. O livro é organizado [...] a partir de anotações e textos escritos para o curso 'Fenomenologia e Currículo', ministrado pelo professor Joel Martins [...] em 1990. [...] seu objetivo é tentar encontrar outra possibilidade de analisar currículo saindo das concepções correntes. O termo currículo é utilizado, então, como equivalente à educação, envolvendo tanto o ensino quanto os programas de estudos" (SOUZA, p. 5, 1993).

2. Apple (1997) exemplifica estas forças, sobretudo, a partir do racismo e do sexismo. Todavia deixa claro a existência de outras formas pelas quais o poder diferencial opera na educação, como as relações de classe, gênero, a soma entre duas ou mais formas, etc. Para além de significar a forma com que o poder diferencial opera no contexto educacional, estas forças também se caracterizam por constituírem as práticas diárias, assim como por serem constituídas e influenciadas por elas. Não são abstrações, apesar de muitos, apropriadamente, as condenarem pelos seus efeitos viscerais.

3. Este saber se responsabiliza pela "expansão de mercados, 'defesa', criação artificial e a estimulação de novas necessidades de consumo, o controle e a divisão do trabalho" (APPLE e WEIS, 1986, p. 21).

4. Ver os sub tópicos "O currículo oculto e as normas do local de trabalho" e "Mulheres no trabalho", do capítulo "O outro lado do currículo oculto: a cultura como experiência vivida - I" da obra "Educação e Poder" de Michael Apple. 
5. Não há como, portanto, do ponto de vista das teorias críticas do currículo alinhadas ao bloco marxista - e justamente por isso tais teorias eximem-se do rótulo "reconceitualista" -, conferir à perspectiva autobiográfica a coerência necessária para classificá-la como uma teoria que verdadeiramente se emprenha a identificação do sentido do currículo. A justificativa que sustenta a tese desta crítica, como dão a entender Moreira e Silva (2005), pressupõe a existência de elementos que expressam contradições existentes nas "experiências vividas", elemento central da perspectiva autobiográfica, que a tornam muito mais próxima de uma perspectiva que se propõe a compreender ações espontâneas do que a estabelecer, propriamente, um sentido ao papel curricular. A compreensão do percurso formativo a partir da "experiência vivida" é contraditória: para a crítica referenciada na presente nota, o caráter subjetivo como valor de conhecimento é pura "compreensão relativista dos fenômenos", isto é, ao tomar a realidade como alvo de interpretação de "experiências vividas", a perspectiva autobiográfica descompromete-se ao estabelecimento de juízo de valor e, por conseguinte, de estranhamento ao natural, por mais que critique a "consolidação natural das atividades cotidianas". Resumidamente, a crítica projetada pelo bloco marxista concebe que, ao se aliar à fenomenologia (ou mesmo ainda à hermenêutica), a autobiografia se aproxima da filosofia, que possui intento divergente ao científico: enquanto a filosofia busca descobrir o sentido da natureza, a ciência compromete-se (ou pelo menos afirma-se como tal) à melhoria da vida humana, portanto grávida do sustentáculo filosófico, a autobiográfica tende a não estranhar o "natural” e tão logo não apontar mudanças sociais, por mais que projete transformações positivas e "emancipatórias" da realidade.

\section{Referências}

ALTHUSSER, Louis. Aparelhos ideológicos do estado: nota sobre os aparelhos ideológicos do estado. 8. ed. Rio de Janeiro: Graal, 2001. 127 p.

APPLE, Michael. Ideologia e currículo. São Paulo: Editora Brasiliense, 1982. 246 p.

APPLE, Michael. Educação e poder. Porto Alegre: Artes Médicas, 1989. 201 p.

APPLE, Michael. O que os pós-modernistas esquecem: capital cultural e conhecimento oficial. In: GENTILI, Pablo; SILVA, Tomaz Tadeu da. (Orgs.). Neoliberalismo, qualidade total e educação. Petrópolis: Vozes, 1995. p. 179-204.

APPLE, Michael. Conhecimento oficial: a educação democrática numa era conservadora. Petrópolis: Vozes, 1997. $267 \mathrm{p}$

APPLE, Michael. Interromper a direita: realizar trabalho educativo crítico numa época conservadora. Currículo sem Fronteiras, v. 2, n. 1, p. 80-98, jan./jun. 2002.

APPLE, Michael. Repensando ideologia e currículo. In: MOREIRA, Antonio Flavio Barbosa. SILVA, Tomaz Tadeu da. (Orgs.). Currículo, Cultura e Sociedade. 8. ed. São Paulo: Cortez, 2005. p. 39-57.

APPLE, Michael. Ideologia e currículo. 3. ed. Porto Alegre: ArtMed, 2006. 288 p.

APPLE, Michael. A educação pode mudar a sociedade?. Petrópolis: Vozes, 2017. 312 p.

APPLE, Michael; AU, Wayne; GANDIN, Luís Armando. O mapeamento da educação crítica. In: APPLE, Michael; AU, Wayne; GANDIN, Luís Armando. (Orgs.). Educação crítica: análise internacional. Porto Alegre: ArtMed, 2011. p. 14-32.

APPLE, Michael; WEIS, Lois. Vendo a educação de forma relacional: classe e cultura na sociologia do conhecimento escolar. Educação \& realidade, Porto Alegre, v. 11, n. 1, p. 19-33, jan./jun. 1986.

BARRIGA, Frida Díaz. Comprender la teoría del currículum como una conversación complicada: surgimiento, crisis, reconceptualización e internacionalización. Revista Mexicana de Investigación Educativa, Cidade do México, v. 21, n. 69, p. 641-646, 2016.

BAUDELOT, Christian; ESTABLET, Roger. La escuela capitalista en Francia. Madrid: Siglo XXI de España Editores, 1976. 302 p.

BOWLES, Samuel; GINTIS, Herbert. La instrucción escolar en la américa capitalista. Madrid: Siglo XXI de España Editores, 1981. 384 p. 
GADOTTI, Moacir. História das idéias pedagógicas. 8. ed. São Paulo: Editora Ática, 2001. 319 p.

GANDIN, Luís Armando. Michael Apple: a educação sob a ótica da análise relacional. In: REGO, Teresa Cristina. (Org.). Currículo e política educacional. Petrópolis: Vozes, 2011. p. 23-52.

MALTA, Shirley Cristina Lacerda. Uma abordagem sobre currículo e teorias afins visando à compreensão e mudança. Espaço do Currículo, João Pessoa, v. 6, n. 2, p. 340-354, mai./ago. 2013.

MARTINI. Renato da Silveira. A fenomenologia e a epochê. Trans/Form/Ação, Marília, v. 21, n. 22, p. 43-51, 1999.

MOREIRA, Antonio Flavio Barbosa; SILVA, Tomaz Tadeu da. Sociologia e Teoria Crítica do Currículo: uma introdução. In: MOREIRA, Antonio Flavio Barbosa; SILVA, Tomaz Tadeu da. (Orgs.). Currículo, Cultura e Sociedade. 8. ed. São Paulo: Cortez, 2005. p. 7-38.

PACHECO, José Augusto. Reconceptualização curricular: os caminhos de uma teoria curricular crítica. Perspectiva, Florianópolis, v. 18, n. 33 p. 11-33, jan./jun. 2000.

PACHECO, José Augusto. Currículo: entre teorias e métodos. Cadernos de Pesquisa, São Paulo, v. 39, n. 137, p. 383-400, mai./ago. 2009.

PACHECO, José Augusto. PEREIRA, Nancy. Estudos curriculares: das teorias aos projectos de escola. Educação em Revista, Belo Horizonte, v. 45, p. 197-221, jun. 2007.

RANGHETTI, Diva Spezia. A pesquisa autobiográfica como espaço de reflexão e ressignificação docente. Revista Eletrônica de Ciências da Educação, Campo Largo, v. 1, n. 3, p. 1-14, 2004.

SAVIANI, Dermeval. Escola e democracia. 42 ed. Campinas: Autores Associados, 2012. 128 p.

SCHWAB, Joseph Jackson; HARPER, William Rainey. The practical: a language for curriculum. New York: Ford Foundation, 1970. 44 p.

SILVA, Maria Aparecida da. História do currículo e currículo como construção histórico-cultural. In: Congresso luso-brasileiro de História da Educação, 6., 2006, Uberlândia. Anais... Uberlândia: EDUFU, v. 1, p. 4820-4828, 2006.

SILVA, Tomaz Tadeu da. Documentos de identidade: uma introdução às teorias do currículo. 3. ed. Belo Horizonte: Autêntica, 2017. 156 p.

SOUZA, Rosa Fátima de. A produção intelectual brasileira sobre currículo a partir dos anos 80. Em Aberto, Brasília, v. 12, n. 58, p. 117-128, abr./jun. 1993.

VIEIRA, Almir Martins; RIVERA, Dario Paulo Barrera. A hermenêutica no campo organizacional: duas possibilidades interpretativistas de pesquisa. Revista Brasileira de Gestão de Negócios, São Paulo, v. 14, n. 44, p. 261-273, jul./set. 2012.

\section{Correspondência}

Júlio César Apolinário Maia: Licenciado em Educação Física pela Universidade Estadual de Goiás - Campus Goiânia ESEFFEGO (UEG-ESEFFEGO). Mestrando em Educação do Programa de Pós-Graduação em Educação da Universidade Federal de Jataí (UFJ). Integra os grupos de estudo/pesquisa: Sociedade, Cultura e Formação Humana e Grupo de Estudos Pedagogia Histórico-Crítica (UFJ); Corpo e Mente e Laboratório de Pesquisas em Lazer, Esporte e Estudos do Corpo (UEG-ESEFFEGO).

E-mail: jcesarm@outlook.com

Orcid: https://orcid.org/0000-0002-7162-2136

Texto publicado em Currículo sem Fronteiras com autorização do autor 